\title{
Technè
}

La science au service de l'histoire de l'art et de la préservation des biens culturels

43 | 2016

Une Europe de la recherche en sciences du patrimoine

\section{MOLAB growth, aims and results}

\section{Bruno Brunetti, Costanza Miliani and Antonio Sgamellotti}

\section{CpenEdition \\ Journals}

\section{Electronic version}

URL: http://journals.openedition.org/techne/592

DOI: 10.4000/techne.592

ISSN: 2534-5168

\section{Publisher}

C2RMF

\section{Printed version}

Date of publication: 1 August 2016

Number of pages: $32-40$

ISBN: 978-2-7118-6338-9

ISSN: $1254-7867$

\section{Electronic reference}

Bruno Brunetti, Costanza Miliani and Antonio Sgamellotti, « MOLAB growth, aims and results », Technè [Online], 43 | 2016, Online since 19 December 2019, connection on 26 July 2020. URL : http:// journals.openedition.org/techne/592; DOI : https://doi.org/10.4000/techne.592

\section{(ब) $(\odot \Theta$}

La revue Technè. La science au service de l'histoire de l'art et de la préservation des biens culturels est mise à disposition selon les termes de la Licence Creative Commons Attribution - Pas d'Utilisation Commerciale - Pas de Modification 4.0 International. 


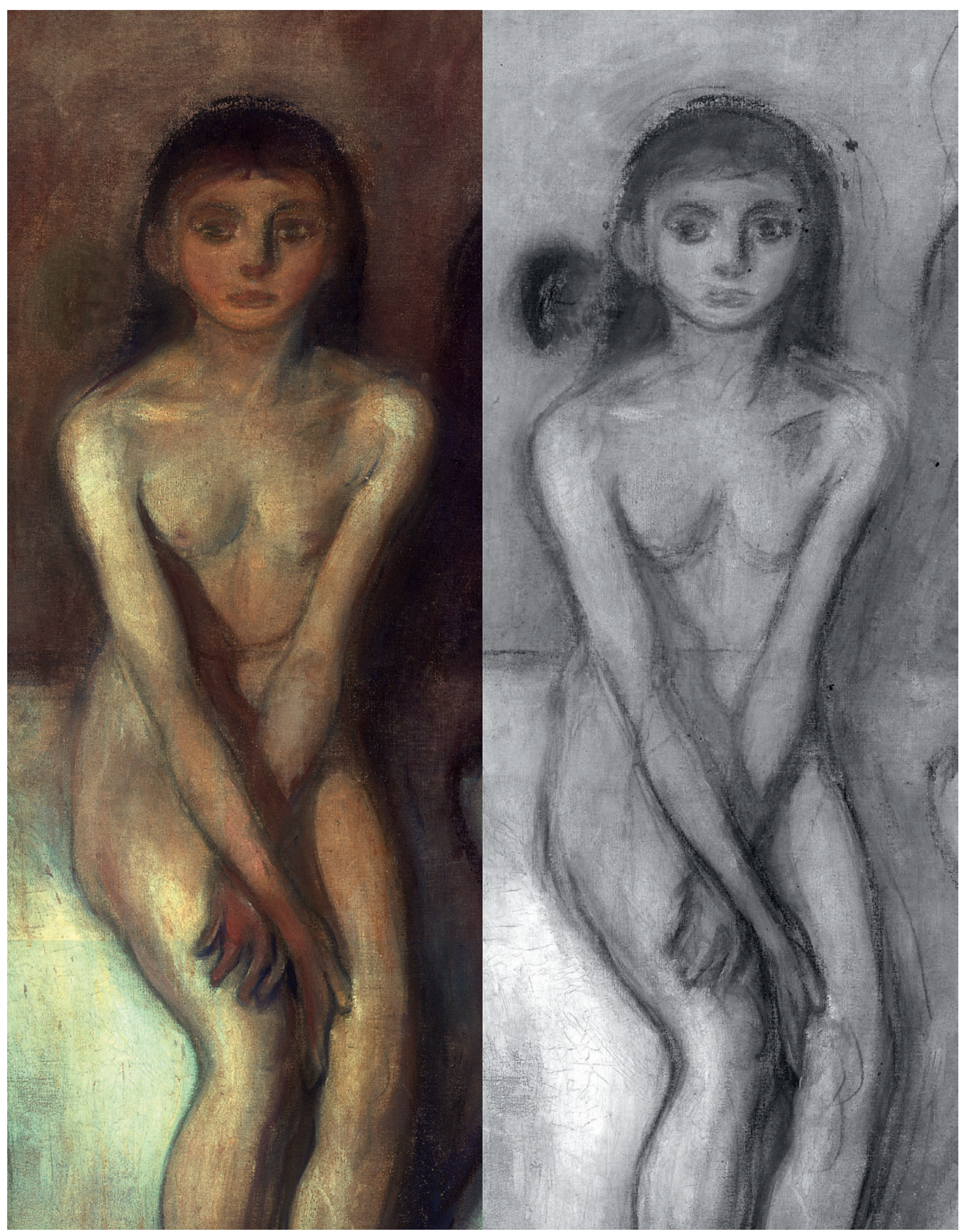

Fig. 1. Multi-band reflectograms acquired on Munch's paintings at the Munch Museet in Oslo.

The underdrawings are outstandingly evident in Puberty, where the position of the girl is defined by tracing several times the edges, as we can appreciate thanks to the numerous corrections in the placing of the head and of the knees. [From ref. 4] () Archetype Publication in association with the University of Oslo. 
Bruno Brunetti Costanza Miliani Antonio Sgamellotti

\section{MOLAB growth, aims and results}

MOLAB : croissance, objectifs et résultats

Résumé. MOLAB est un ensemble unique d'instruments mobiles intégrés créé en Italie en 2001 et disponible à un accès transnational depuis 2004 dans le cadre des programmes européens Eu-ARTECH $\left(\sigma^{e} P C\right)$ et CHARISMA ( $\left.7^{p} P C\right)$. Son utilisation a démontré au cours des dix dernières années que l’on peut obtenir des résultats analytiques de qualité par des travaux in situ sur différents types d'objets $d u$ patrimoine sans avoir à prélever des échantillons ou à les transporter dans un laboratoire, et recueillir des informations importantes sur la nature et le comportement des matériaux organiques et inorganiques de l'objet examiné. Les méthodes in situ et non invasives du MOLAB ont favorisé une inflexion notable des pratiques diagnostiques, une augmentation de la production scientifique dans les sciences $d u$ patrimoine et la conservation-restauration, ainsi qu'une évolution positive des relations entre conservateurs de musées, restaurateurs et chercheurs, contribuant à l'adoption d'un langage commun et au renforcement des collaborations. Lintroduction récente de systèmes mobiles dimagerie en $2 D$ et en $3 D$, mis au point grâce aux activités conjointes de recherche de CHARISMA, a considérablement élargi la gamme des outils du MOLAB disponibles dans le cadre du projet en cours IPERION CH (horizon 2020), accroissant ici le nombre et les motivations des utilisateurs potentiels en Europe et dans les pays associés.

Mots-clés. Mesures in situ, techniques non invasives, analyse non-destructive, instruments d'imagerie, peintures, manuscrits, céramiques.
Abstract. MOLAB is a unique collection of integrated mobile instrumentation established in Italy in 2001 and open from 2004 to transnational access within the European projects Eu-ARTECH (FP6) and CHARISMA (FP7). Its application demonstrated in the last decade that satisfactory analytical results can be obtained through in situ studies of a variety of heritage objects without sampling or moving them to a laboratory, achieving significant overviews on nature and behavior of the inorganic and organic materials of the examined object. The MOLAB in situ noninvasive approach produced a significant change in diagnostic practices, an increase of scientific inputs in heritage studies and conservation, and a positive modification in the relationships between curators, conservators, and scientists, permitting a common language to be established and partnership strengthened. The recent introduction of innovative mobile $2 D$ and $3 D$ imaging systems, setup within the CHARISMA joint research project, significantly extended the MOLAB tools available in the current project IPERION CH (Horizon 2020), widening number and interest of potential users from Europe and associated countries.

Keywords. In situ measurements, non-invasive techniques, non-destructive analysis, imaging instrumentation, paintings, manuscripts, ceramics.
Le MOLAB est une collection unique d'instruments mobiles intégrés utilisant des méthodes spectroscopiques non invasives qui exploitent la lumière, de l'infrarouge moyen aux rayons $\mathrm{X}$, et qui travaillent en mode point ou en balayage ${ }^{1}$. Fondée en 2001 à l'Université de Pérouse (UNIPG) en collaboration avec l'Institut des sciences et des technologies moléculaires du CNR (ISTM-CNR), le MOLAB a été conçu comme une plateforme mobile qui permet aux scientifiques, aux conservateurs-restaurateurs, aux historiens de l'art et aux archéologues de mener des études scientifiques sur les matériaux du patrimoine culturel lorsque l'échantillonnage est interdit
MOLAB is a unique collection of integrated mobile instruments based on non-invasive spectroscopic methods exploiting light from mid-infrared to X-ray and working in point or scanning mode ${ }^{1}$. Founded in 2001 at Perugia University (UNIPG) in collaboration with the Institute of Molecular Science and Technology of CNR (ISTM-CNR), MOLAB has been conceived as a mobile facility which allows scientists, conservators, art historians and archaeologists to carry out scientific studies on cultural heritage materials when sampling is prohibited or when the bad state of conservation or the dimensions of the examined object advise them against any

Bruno Brunetti, Professeur au Centre SMAArt et au département de Chimie, Biologie et Biotechnologie, Université de Pérouse, Italie. Affilié au ISTM-CNR, Italie (bruno@dyn.unipg.it). Costanza Miliani, chercheur au ISTM-CNR, Istituto di Scienze e Tecnologie Molecolari du CNR et membre du Centre SMAArt, Université de Pérouse, Italie (costanza.miliani@cnr.it). Antonio Sgamellotti, membre de l’Accademia Nazionale dei Lincei, professeur émérite à l’Université de Pérouse. Affilié au ISTM-CNR, Italie (sgam@thch.unipg.it). 
ou lorsque le mauvais état de conservation ou les dimensions de l'objet examiné contre-indiquent tout transport vers un laboratoire. Depuis 2004, le MOLAB a été le premier (et unique) accès transnational mobile soutenu par la Commission européenne. À travers les projets Eu-ARTECH et CHARISMA, des fournisseurs d'accès comme l'UNIPG/ISTM-CNR (Pérouse), l'INO-CNR (Institut National d'Optique du CNR, Florence) et le CNRS-C2RMF/LAMS (Centre de Recherche et de Restauration des Musées de France/Laboratoire d'archéologie moléculaire et structurale, Paris - UMR avec le CNRS) ont mis à la disposition des utilisateurs transnationaux un ensemble de 15 équipements portables différents pour le développement de travaux in situ et non invasifs de diagnostic et de conservation, sans échantillonnage, ni contact avec l'œuvre d'art examinée.

Grâce à l'utilisation de la plateforme MOLAB, des études réussies ont été menées à travers de nombreux projets par des centaines d'utilisateurs, effectuant des mesures sur différents types d'objets du patrimoine, y compris des peintures, des sculptures, des manuscrits et des céramiques ${ }^{1,2}$. En particulier, en ce qui concerne les peintures, des études sur les techniques d'exécution (par exemple, l'enregistrement des dessins sous-jacents, l'identification des matériaux d'origine et la cartographie de leur distribution) ont été réalisées sur des œuvres de maîtres anciens, modernes et contemporains, comme Bronzino, Léonard de Vinci, Le Caravage, Renoir, Cézanne, Van Gogh, Munch, Picasso, Mondrian, de Staël et beaucoup d'autres ${ }^{2}$. Des manuscrits enluminés ont également été étudiés, comme le Livre de Kells, des codex mexicains précolombiens et d'autres ${ }^{3}$, ainsi que des céramiques, comme des céramiques lustrées de la Renaissance italienne ${ }^{1}$ et les premières porcelaines de Saxe.

Des études exemplaires de dessins sous-jacents ont été réalisées à l'aide d'un scanner multi-bandes fonctionnant dans le proche infrarouge. Le système recueille simultanément un ensemble d'images à différentes longueurs d'onde avec un pas de $100 \mathrm{~nm}$ dans la gamme 800-2300 nm. L'ensemble des données résultant est un cube d'images qui peut être coupé en réflectogrammes multi-bandes, libres de toute distorsion géométrique. À titre d'exemple, l'étude des réflectogrammes multi-bandes acquis à partir de peintures de Munch au Musée Munch à Oslo, ont permis à B. Topolova-Casadiego et ses collaborateurs de visualiser les différentes traces des dessins sous-jacents ${ }^{4}$, en particulier dans Puberté, 1894 (fig. 1), et dans Vampire, 1895, où le peintre, après avoir fait une esquisse des personnages avec un fusain ou un crayon à mine de plomb, a affiné la composition en lavis, à l'aide d'une brosse.

La caractérisation d'une large gamme de pigments a été réalisée de manière non invasive en utilisant la méthode analytique intégrée MOLAB basée sur l'analyse élémentaire SFX, suivie d'analyses moléculaires, à savoir par IRTF proche et moyen, par absorption et émission UV-Vis, par spectroscopie Raman et/ou par diffraction des rayons X. À titre d'exemple de l'identification moléculaire de différents pigments, nous présentons des résultats concernant le tableau Ferry Boat à Anvers par Jacob Jordaens (c. 1623). L'œuvre a été étudiée au transportation to a laboratory. Since 2004, MOLAB has been the first (and unique) mobile transnational access supported by the European Commission. Through the Eu-ARTECH and CHARISMA projects, providers as UNIPG/ISTM-CNR (Perugia), INO-CNR (National Institute of Optics of CNR, Firenze) and CNRS-C2RMF/LAMS (Centre of Research and Restoration of French Museums/Laboratory of Molecular and Structural Archaeology, Paris - a joint research unit with CNRS) made available to transnational users a set of 15 different portable equipments for the non-invasive in situ development of diagnostic/conservation work, with neither sampling nor contact with the examined work of art.

Thanks to the use of the MOLAB facility, successful studies have been carried out in numerous projects by hundreds of users, carrying out measurements on different types of heritage objects, including paintings, sculptures, manuscripts, and ceramics ${ }^{1,2}$. In particular, regarding paintings, studies on execution techniques (e.g. recording of underdrawings, identification of original materials and mapping of their distribution), have been carried out on works of ancient, modern and contemporary masters, as Bronzino, Leonardo, Caravaggio, Renoir, Cézanne, Van Gogh, Munch, Picasso, Mondrian, de Stael, and many others ${ }^{2}$. Illuminated manuscripts have been also studied, as the Book of Kells, pre-Columbian Mexican codices ${ }^{3}$ and others, and ceramics, as Renaissance Italian lusterwares ${ }^{1}$ and early Meissen porcelains.

Exemplary studies of underdrawings were carried out using a multi-band scanner operating in the near infrared range. The system simultaneously collects a set of images at different wavelengths, with a step of $100 \mathrm{~nm}$ in the 800-2300 $\mathrm{nm}$ range. The resulting dataset is an image cube that can be sliced in multi-band reflectograms free of any geometrical distortion. As an example, the study of multi-band reflectograms acquired on Munch's paintings at the Munch Museum in Oslo, allowed B. Topolova-Casadiego and co-workers to visualize different traces of underdrawings ${ }^{4}$, especially in Puberty, 1894 (fig. 1), and in Vampire, 1895, where the painter, after sketching the figures with a charcoal or graphite pencil, refined the composition in wash, using a brush.

Wide characterization of pigments has been achieved non-invasively exploiting the MOLAB integrated analytical method based on XRF elemental analysis, followed by molecular investigations, namely by near- and mid-FTIR, UV-Vis absorption and emission, and Raman spectroscopy and/or $\mathrm{X}$-ray diffraction. As an example of the molecular recognition of different pigments, we report some results concerning the painting The Ferry Boat from Antwerp by Jacob Jordaens (c. 1623). The artwork was studied at the Statens Museum for Kunst in Copenhagen (fig. 2) where one of the questions addressed by the users was the identification and mapping of blue pigments over the painting surface. Indigo and smalt were found on original areas such as on the woman's skirt (fig. 2). Jordaens used the organic dye as a dark underpaint, highlighted by partially discolored smalt brushstrokes. He applied azurite to color both the sky and the sea, often mixed with malachite and lead white. Besides the original pigments, 
a
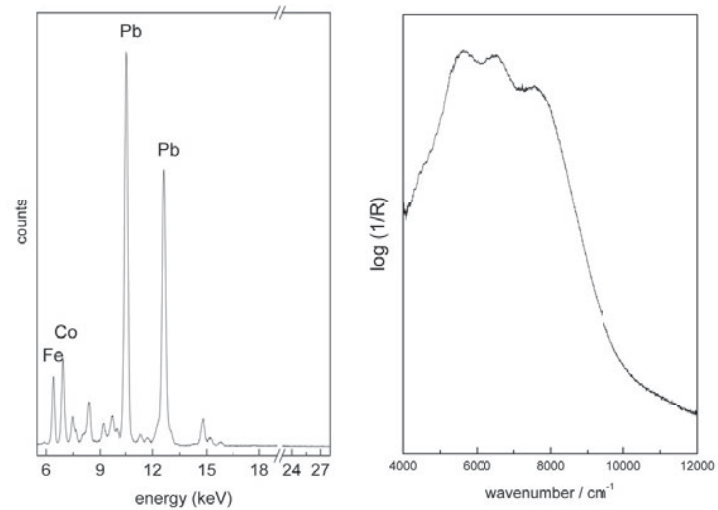

$\mathrm{b}$
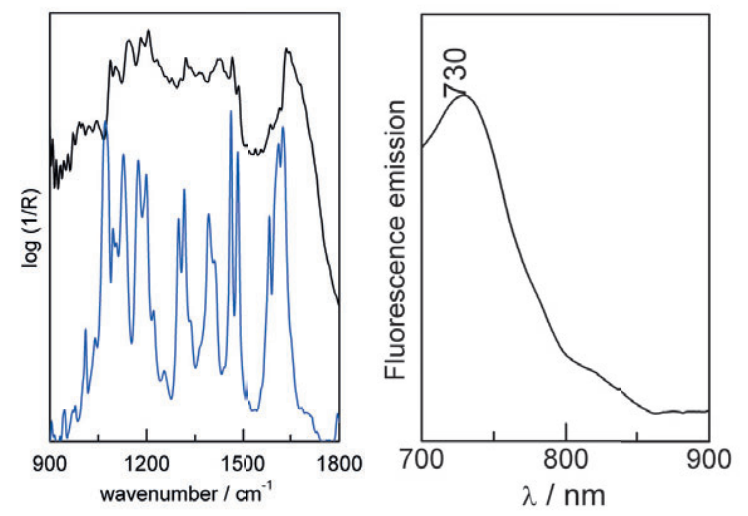

C
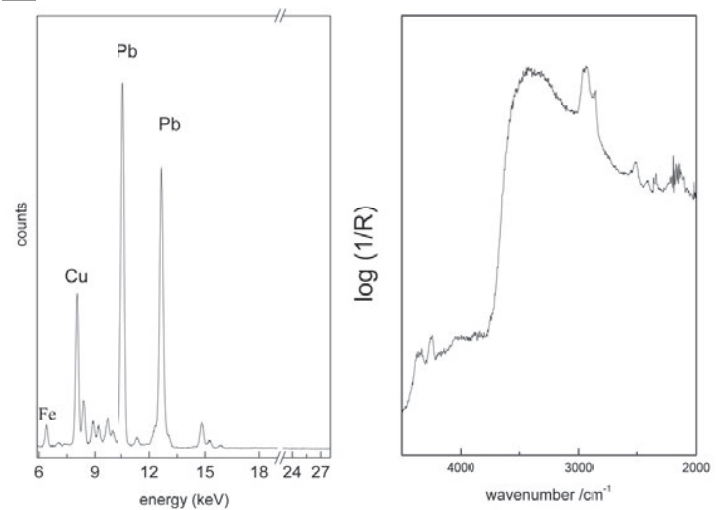

\section{d}
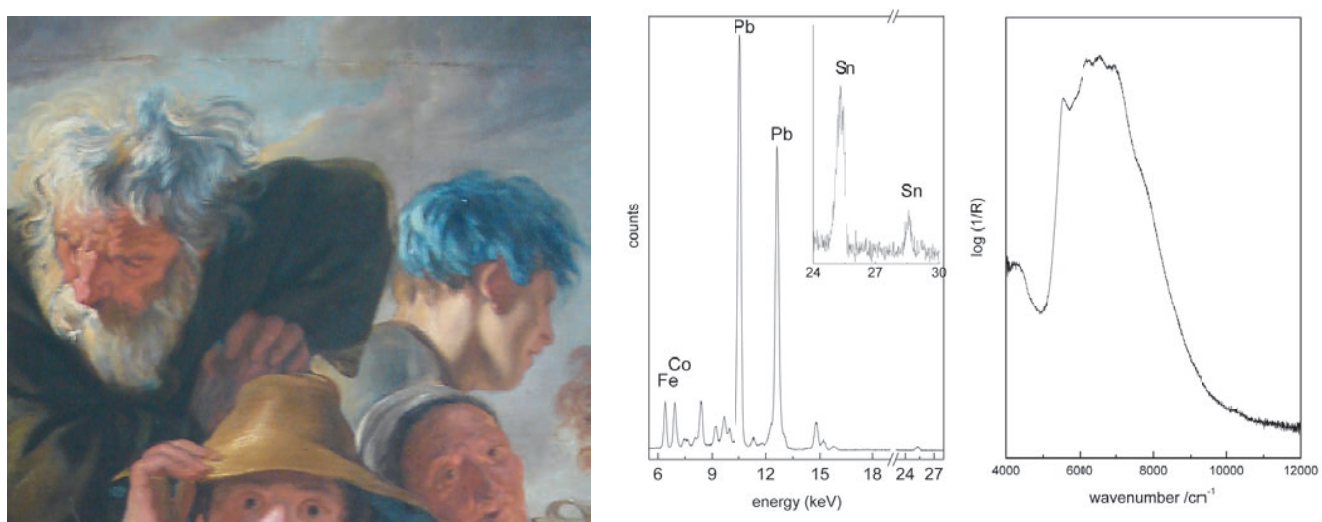

e
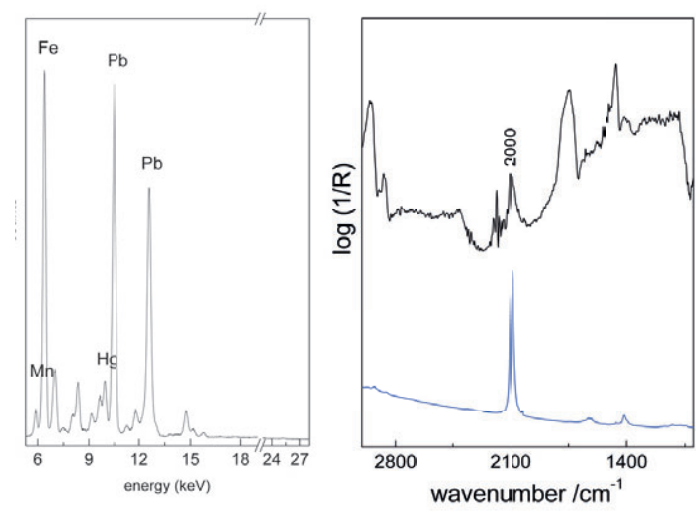

$f$

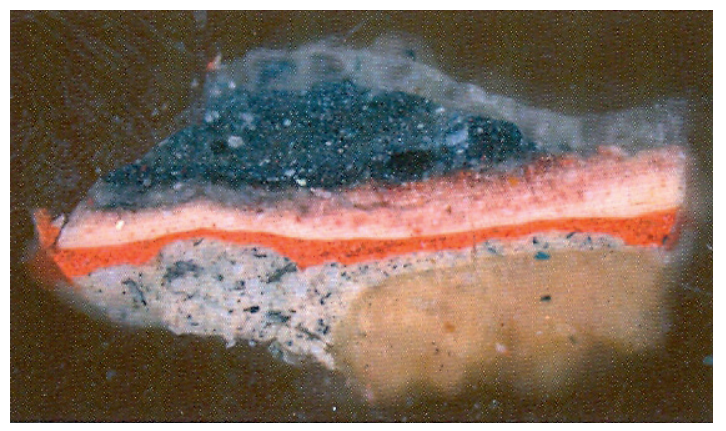

Fig. 2. Study of blue pigments of The Ferry Boat from Antwerp (c. 1623) by Jordaens at the Statens Museum for Kunst in Copenhagen (a detail of the painting is shown in the middle). (a) smalt has been identified on the basis of Co signals in XRF spectra (left) and near-FTIR (right) evidencing the typical shape of the $d-d$ transition of Co(II) in pseudo-tetrahedral coordination; (b) indigo has been identified on the basis of mid-FTIR (left) features and the UV-vis fluorescence emission at $730 \mathrm{~nm}$ (right); (c) azurite has been identified by the presence of the Cu signal in XRF (left) and mid-FTIR combination bands (right); (d) cerulean blue has been distinguished from smalt by the signal of Sn in XRF (left) and by the different position and shape of the Co(II) transition in the near-FTIR (right); (e) Prussian blue has been identified by the strong CN asym. stretching in the mid-FTIR spectrum. Inset in (f) shows the optical image of a cross-section taken from the skirt of the woman on the boat. [From ref. 1] ๔ American Chemical Society. 
Statens Museum for Kunst à Copenhague (fig. 2) où l'une des questions posées par les utilisateurs a été l'identification et la cartographie des pigments bleus sur la surface de la peinture. De l'indigo et du smalt ont été trouvés sur des zones originales comme la jupe de la femme (fig. 2). Jordaens a utilisé le colorant organique comme une sous-couche sombre rehaussée par des coups de pinceaux de smalt partiellement décolorés. Il a appliqué de l'azurite pour colorer à la fois le ciel et la mer, souvent mélangée avec de la malachite et du blanc de plomb. Outre les pigments d'origine, deux autres composés bleus (bleu céruléen et bleu de Prusse, non compatibles temporellement avec l'époque de Jordaens) ont été révélés et attribués aux premières restaurations datant de 1797-1884, probablement réalisées pour dissimuler la décoloration de smalt.

Il a été récemment démontré que l'approche non invasive et in situ du MOLAB était aussi appropriée pour faire la distinction entre des pigments ayant des compositions et des structures chimiques similaires, comme ceux appartenant aux classes chimiques suivantes: $\mathrm{Pb}_{2} \mathrm{Sb}_{2-\mathrm{x}} \mathrm{Y}_{\mathrm{x}} \mathrm{O}_{7-\mathrm{x} / 2}(\mathrm{Y}=\mathrm{Sn}, \mathrm{Zn}, \mathrm{Fe}$, $\mathrm{Pb})$ qui présentent un intérêt dans les études des céramiques émaillées de la Renaissance ou $\mathrm{PbCr}_{1-\mathrm{x}} \mathrm{S}_{\mathrm{x}} \mathrm{O}_{4}$ ([1-x] $\mathrm{PbCrO}_{4} \bullet$ $\mathrm{xPbO})$ et $\mathrm{Cd}_{1-\mathrm{x}} \mathrm{Zn}_{\mathrm{x}} \mathrm{S}$ et $\mathrm{CdS}_{1-\mathrm{x}} \mathrm{Se}_{\mathrm{x}}$ qui sont des pigments synthétiques jaune, orange ou rouge largement utilisés par des peintres modernes et contemporains ${ }^{2}$. Sur ce point, la possibilité d'identifier et de cartographier la répartition des différents types de jaunes de chrome (JC, $\left.\mathrm{PbCr}_{1-\mathrm{x}} \mathrm{S}_{\mathrm{x}} \mathrm{O}_{4}\right)$ a suscité l'intérêt des chercheurs qui s'intéressent aux questions liées à la conservation des peintures de Van Gogh. En fait, l'assombrissement des JC, provoqué par la photo-réduction des chromates d'origine en composés $\mathrm{Cr}$ (III), est favorisé lorsque le pigment est présent dans la forme riche en $\mathrm{S}$ de $\mathrm{PbCr}_{1-\mathrm{x}} \mathrm{S}_{\mathrm{x}} \mathrm{O}_{4}(\mathrm{x}>0,4$, également appelé jaune de chrome sensible à la lumière $=\mathrm{JC}-\mathrm{SL})^{5}$. Dans la fig. 3, les profils Raman de différents JCs, obtenus sur des tableaux de Van Gogh (au musée Van Gogh à Amsterdam, MVG), et la localisation des différentes formes de jaunes de chrome et d'autres pigments sur les Tournesols (MVG), tel que déterminée par spectroscopie Raman, sont présentés.

Dans le cadre de diagnostics effectués pour la conservation, un grand nombre de projets d'accès MOLAB ont été menés par des utilisateurs souhaitant évaluer la distribution à la surface d'un tableau des composés d'altération et/ou de migration (par exemple, des oxalates, des carboxylates métalliques et des tensioactifs). À titre d'exemple, les spectres d'IRTF moyen de réflexion indiquant la présence d'oxalates de cuivre obtenus au cours de différents projets MOLAB ${ }^{6}$ sont présentés dans la figure 4. Dans un autre exemple, B. Ormsby et ses collaborateurs ${ }^{7}$ ont exploité la spectroscopie IRTF moyen portable (fig. 5) et la microscopie à force atomique pour documenter les différences relatives d'abondance des tensioactifs de surface sur les peintures acryliques en fonction de la marque de la peinture, du type de pigment et des changements induits par les traitements de nettoyage de la surface, en faisant la différence entre les effets des systèmes de solvants aqueux et aliphatiques ${ }^{7}$.

Le programme d'accès MOLAB a eu un impact considérable sur la communauté des sciences du patrimoine, a further two blue compounds (cerulean blue and Prussian blue, not temporally compatible with Jordaens's period) were revealed and assigned to early restorations, dating back to 1797-1884, probably carried out to disguise the discoloration of smalt.

The MOLAB non-invasive in situ approach has been recently demonstrated to be suitable also for the discrimination among pigments sharing similar chemical compositions and structures, as those belonging to the following chemical classes: $\mathrm{Pb}_{2} \mathrm{Sb}_{2-\mathrm{x}} \mathrm{Y}_{\mathrm{x}} \mathrm{O}_{7-\mathrm{x} / 2}(\mathrm{Y}=\mathrm{Sn}, \mathrm{Zn}, \mathrm{Fe}, \mathrm{Pb})$ of interest in studies on Renaissance glazed ceramics, or $\mathrm{PbCr}_{1-\mathrm{x}} \mathrm{S}_{\mathrm{x}} \mathrm{O}_{4}$, (1-x) $\mathrm{PbCrO}_{4} \cdot \mathrm{xPbO}$ and $\mathrm{Cd}_{1-\mathrm{x}} \mathrm{Zn}_{\mathrm{x}} \mathrm{S}$ and $\mathrm{CdS}_{1-\mathrm{x}} \mathrm{Se}_{\mathrm{x}}$ which are yellow, orange or red synthetic pigments widely used by modern and contemporary painters ${ }^{2}$. On this regard, the possibility to identify and map the distribution of different type of chrome yellows $\left(\mathrm{CY}, \mathrm{PbCr}_{1-\mathrm{x}} \mathrm{S}_{\mathrm{x}} \mathrm{O}_{4}\right)$ has attracted the interest of scholars dealing with issues related to the conservation of Van Gogh's paintings. In fact, the darkening of CY, caused by the photoreduction of original chromates to $\mathrm{Cr}$ (III)-compounds, is favored when the pigment is present in the S-rich form of $\mathrm{PbCr}_{1-\mathrm{x}} \mathrm{S}_{\mathrm{x}} \mathrm{O}_{4}(\mathrm{x}>0.4$, also called light sensitive chrome yellow $=\mathrm{LS}-\mathrm{CY})^{5}$. In fig. 3, Raman profiles of different CYs, as recorded on Van Gogh's paintings (at the Van Gogh Museum in Amsterdam, VGM), and localization of different forms of chrome yellows and other pigments on the Sunflowers (VGM), as determined by Raman spectroscopy, are reported.

In the context of diagnostics for conservation, a wide number of MOLAB access projects have been carried out by users interested to assess the distribution of alteration and/ or migration compounds (e.g. oxalates, metal carboxylates and surfactants) at the surface of a painting. As an example, reflection mid-FTIR spectra indicating the presence of copper oxalates collected during different MOLAB projects ${ }^{6}$ are shown in fig. 4. As a further example, B. Ormsby and cowork$\mathrm{ers}^{7}$ exploited portable mid-FTIR spectroscopy (fig. 5) and atomic force microscopy (AFM) for documenting relative differences in surface surfactant abundance on acrylic paintings with respect to: paint brand, pigment type, and changes induced by surface cleaning treatments, differentiating between the effects of aqueous and aliphatic solvent systems ${ }^{7}$.

The MOLAB access program registered an outstanding impact on the heritage science community, promoting a large diffusion of the scientific approach to the study and conservation of artworks and stimulating discussions on results among scientists, scholars and professionals in conservation that strongly contributed to the creation of a common language between them, overcoming the barrier possibly imposed by the different disciplinary ground.

The MOLAB platform has been recently upgraded in the current IPERION CH project with new instruments including advanced mapping/imaging multi/hyperspectral tools for $2 \mathrm{D}$ and $3 \mathrm{D}$ examinations. Five of the new MOLAB instruments are prototypes specifically developed within the CHARISMA joint research activities for measurements of Single-Sided NMR Depth Profiling (NMR-MOUSE), integrated 


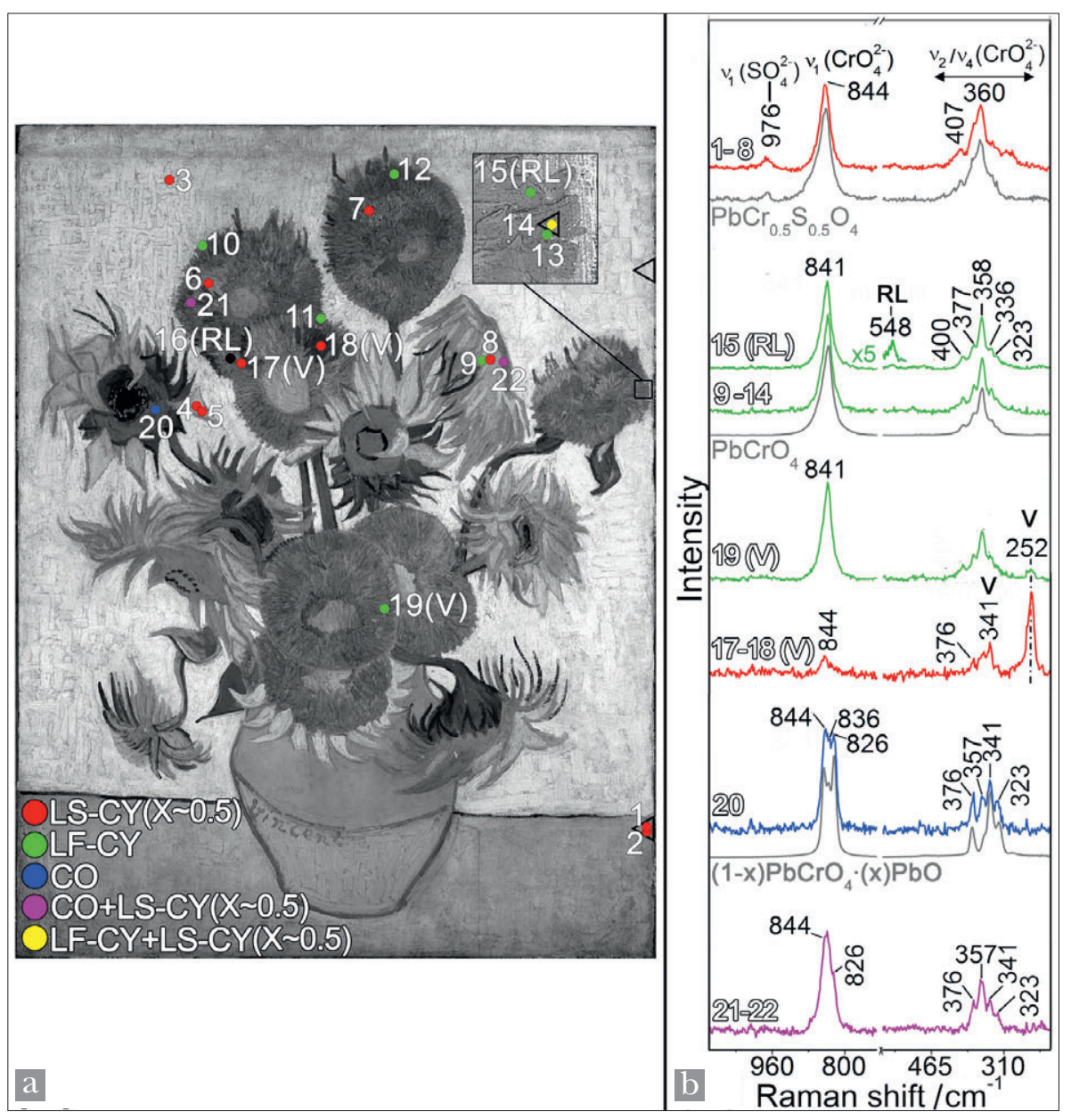

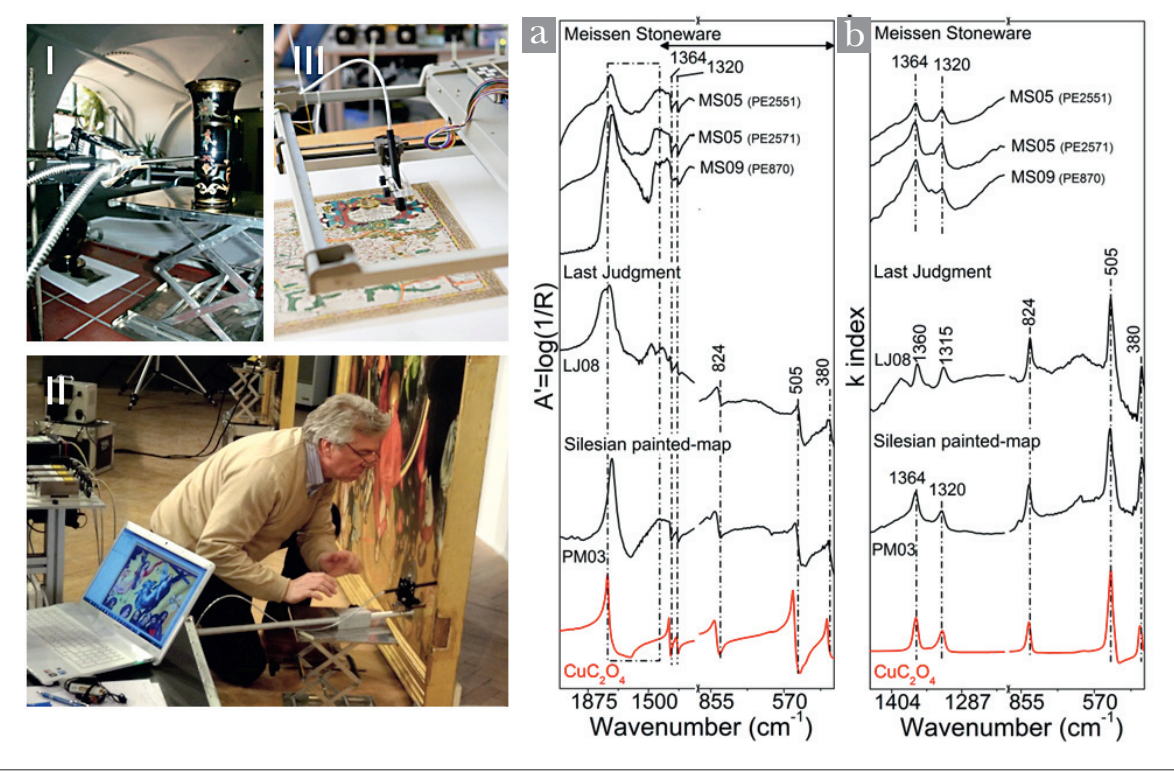

Fig. 4. Identification and mapping of Cu oxalates. Photographs refer to MOLAB in situ measurements on: (I) a painted early Meissen Stoneware (18th C) at the State Art Collections, Dresden, DE , (II) a panel of the altarpiece painting Last Judgment (1465-1471) by H. Memling at the National Museum, Gdansk, PL; (III) a Silesian painted map of 17th-18th century at the Ossolinski National Institute, Wroclaw, PL. Corresponding in situ mid-FTIR spectra in pseudoabsorbance (a) and after Kramers-Krönig correction (b). [Rearrangement from ref. 6] (c) Photo MOLAB.
Fig. 3. (A) Distribution of different forms of chrome yellows and other pigments on Sunflowers (Van Gogh Museum, Amsterdam): LS-CY=light sensitive chrome yellow; LF-CY: lightfast chrome yellow; $\mathrm{CO}=$ chrome orange; $\mathrm{V}=$ vermilion; $\mathrm{RL}=$ red lead

(B) Selection of Raman profiles acquired from yellow areas of the painting. $V$ and $\mathrm{RL}$ indicate spectra recorded where chrome yellow is mixed with vermilion and red lead. [From ref. 5] (C) With permission of John Wiley and Sons.
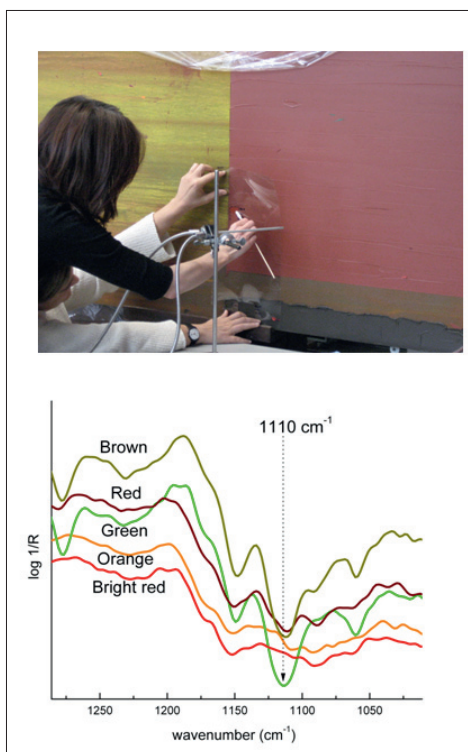

Fig. 5. Reflectance mid-IR spectra from the surface of several paint passages on John Hoyland's 25.4.69 (1969) at The Tate Modern, London, showing the presence of PEO surfactant (largest band at ca. $1110 \mathrm{~cm}^{-1}$ ) on the brown, red and green paints. [From ref. 7] (c) Photo MOLAB. 
encourageant une large diffusion d'une approche scientifique de l'étude et la conservation des œuvres d'art, et stimulant des discussions sur les résultats entre les scientifiques, les spécialistes et les professionnels de la conservation, ce qui a fortement contribué à la création d'un langage commun permettant de surmonter la barrière éventuellement imposée par les différents champs disciplinaires.

La plateforme MOLAB a récemment été améliorée dans le cadre du projet en cours IPERION CH avec de nouveaux instruments, y compris des outils avancés de cartographie/ imagerie multi/hyperspectrale pour des examens en 2D et 3D. Cinq des nouveaux instruments de MOLAB sont des prototypes spécifiquement développés au cours d'activités conjointes de recherche de CHARISMA : des mesures de profil en profondeur par RMN par face avant (NMR-MOUSE), la spectroscopie d'absorption-émission couplée à la fluorescence résolue en temps, la spectroscopie et l'imagerie térahertz (T-Hz), l'interférométrie holographique de Speckle (DHSPI) et la tomographie en cohérence optique (TCO).

Le système portable de spectroscopie $\mathrm{T}-\mathrm{Hz}$ dans le domaine temporel est capable d'obtenir des informations in situ à partir des différentes couches d'échantillons stratifiés. Il permet, par exemple, la caractérisation (identification/ visualisation) de sous-couches cachées, comme dans le cas des peintures de chevalet et des peintures murales. Une cartographie 2D et 3D sur et dans les objets inspectés peut également être effectuée en utilisant le temps de $\mathrm{vol}^{8}$.

Le nouveau dispositif de DHSPI, une amélioration d'une version précédente, permet un diagnostic non-destructif de l'état structurel d'un objet, par la détection des fissures, des détachements ou d'autres défauts. Les altérations révélées peuvent être situées sur la surface et à l'intérieur de l'objet et sont détectées sous la forme de franges d'interférence. À partir des mesures, une carte des risques est créée, après l'analyse quantitative de la densité de franges par unité de surface ${ }^{9}$.

L'analyse par TCO contribue à la détermination de la structure des couches superficielles d'une peinture à condition qu'elles soient assez transparentes au rayonnement infrarouge proche. En particulier, elle permet d'effectuer des études sur les vernis détériorés, les glaçures, les repeints et les retouches. Les objets anciens en verre peuvent être également étudiés, ainsi que les émaux sur les céramiques et les pierres semitransparentes, comme les jades, ou d'autres matériaux. En raison du compromis nécessaire entre la résolution et la profondeur de l'analyse, le système TCO développé par le projet CHARISMA se compose d'un instrument de domaine spectral très compact équipé d'une source super-luminescente (longueur d'onde centrale $870 \mathrm{~nm}$, bande passante $200 \mathrm{~nm}$, $0,8 \mathrm{~mW}$ au niveau de l'objet) avec une résolution axiale (dans l'air) de $3,1 \mu \mathrm{m}$ et une résolution latérale de $13 \mu \mathrm{m}$. En utilisant cet appareil, des études ont été menées à bien et, parmi plusieurs exemples, nous signalons l'étude du vernis de la Madone aux fuseaux de Léonard de Vinci à l'OPD à Florence, où le nombre, la profondeur et les dimensions des retouches ont été caractérisés en détail. L'imagerie TCO par la face avant à différentes profondeurs (séparées par détection
Absorption-Emission spectroscopy and Fluorescence Decay, Terahertz spectroscopy and imaging (T-Hz), Digital Holographic and Speckle Pattern Interferometry (DHSPI) and Optical Coherence Tomography (OCT).

The portable T-Hz Time Domain Spectroscopy system is capable to retrieve information in situ from different layers within stratified samples. It allows, for example, the characterization (identification/visualization) of hidden sub-layers to be achieved, as in easel and mural paintings. A 2D and 3D mapping on and in the inspected objects can be also carried out using the time of flight ${ }^{8}$.

The new DHSPI device is an improvement of a preceding version suitable for non-destructive diagnosis of the structural condition of an object, by detecting cracks, detachments, or other defects. The revealed alterations can be located on the surface and in the interior of the object and are detected in the form of interference patterns. From the measurements, a risk-map is created, after the quantitative analysis of the fringe density per surface unit ${ }^{9}$.

OCT examination aides in resolving the structure of primary layers on a painting, provided they are transparent enough to near-IR radiation. In particular, it allows useful applications to be carried out for studies of deteriorated varnishes, glazes, over-paintings, and retouchings. Ancient glass artefacts can be profitably also investigated, as well as glazes on ceramics and semitransparent stones, as jades or other materials. As a result of balance between resolution and depth of examination, the OCT system developed within CHARISMA consists of a very compact spectral domain instrument equipped with a super-luminescent source $(870 \mathrm{~nm}$ central wavelength, $200 \mathrm{~nm}$ bandwidth, $0.8 \mathrm{~mW}$ at the object) with $3.1 \mu \mathrm{m}$ axial resolution (in air) and $13 \mu \mathrm{m}$ lateral resolution. Using this device, successful studies have been carried out and, among several examples, we report the study of the varnish of the Leonardo's Madonna dei Fusi at OPD in Firenze, where number, depth and dimension of retouchings were characterized in detail. Front OCT imaging at various depths (separated by coherent detection), made possible to establish the sequence of varnish layers in restored areas, as well as to recover the outline of the retouching and compare it to the contour of actual paint losses ${ }^{10}$. Exemplary slices of such a multilayer structure are shown in fig. 6 .

The enhancement of MOLAB TNA capabilities in 2D and $3 \mathrm{D}$ examination meets the current demands of advanced research in heritage science, not only to reveal the chemical composition of materials but also to map their spatial distribution. Thus, the introduction of the new cutting edge imaging systems currently extends the interest in MOLAB, widening the user groups to new potential users. 

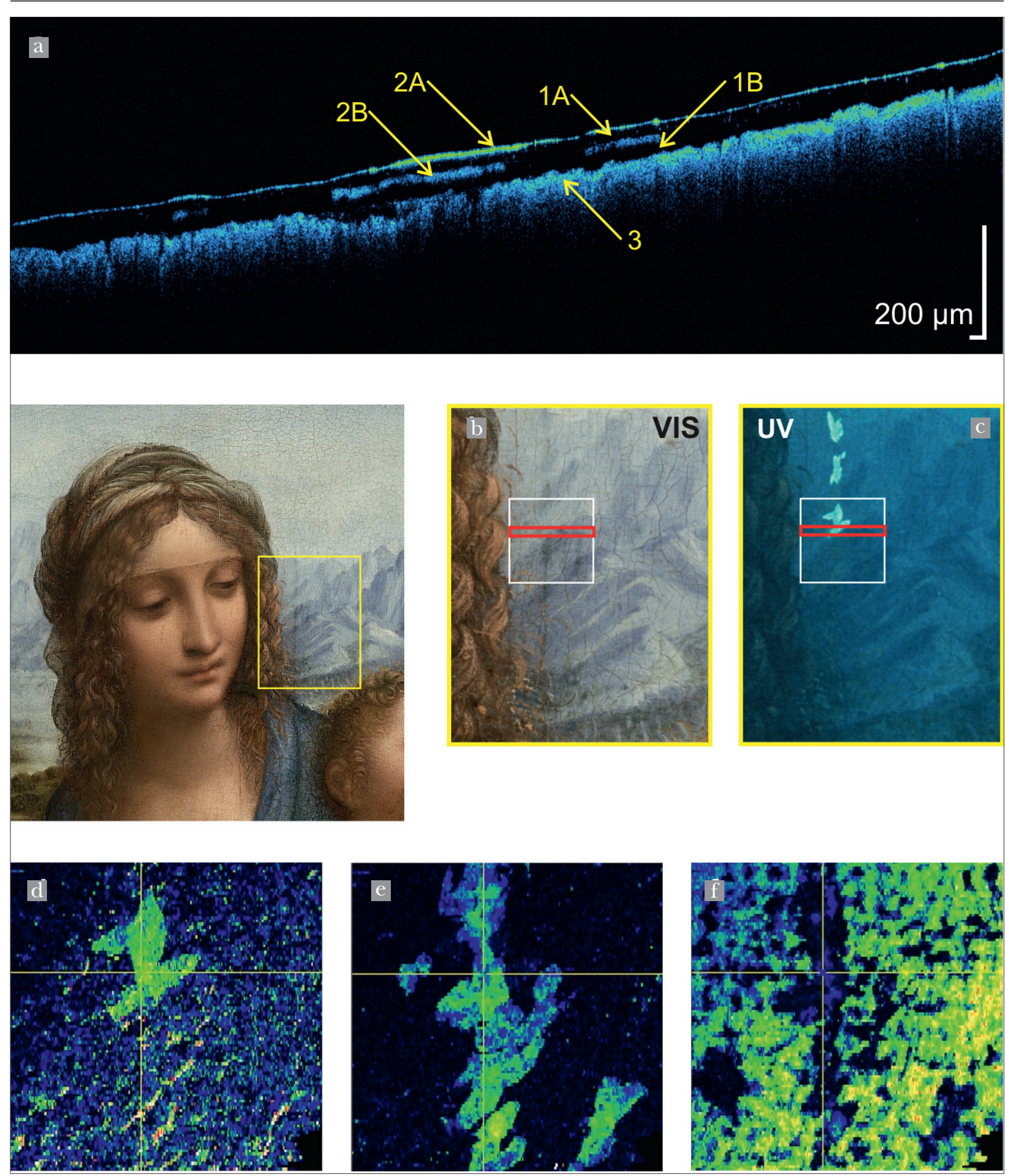

Fig. 6. Results of the OCT examination of the painting Madonna dei Fusi (private collection), attributed to Leonardo da Vinci (16th C.), oil on wood (detail); (a) OCT tomogram from the region indicated by red bars in pictures $(b, c) ;(d, e, f)$ OCT front images at different depths under the surface $(6,18,35 \mu \mathrm{m}$ respectively). (1A, 1B) varnishes, (2A, 2B) two stages of retouching, (3) primary paint layer. [From ref. 10] $\odot$ With permission of Springer/Photo OPD. 
cohérente) a permis d'établir la séquence des couches de vernis dans les zones restaurées, ainsi que de retrouver le contour des retouches et de les comparer au contour des pertes réelles de peinture ${ }^{10}$. Des coupes représentatives d'une telle structure multicouches sont représentées sur la fig. 6 .

Le renforcement des capacités d'examen en 2D et 3D de l'accès transnational MOLAB répond aux exigences actuelles de la recherche de pointe en sciences du patrimoine, non seulement pour révéler la composition chimique des matériaux, mais aussi pour cartographier leur répartition spatiale. Ainsi, l'introduction de nouveaux systèmes d'imagerie de pointe accroît actuellement l'intérêt porté au MOLAB, élargissant le groupe des utilisateurs à de nouveaux utilisateurs potentiels.

\section{Remerciements}

Les activités du MOLAB décrites dans cet article ont été rendues possible grâce au soutien de la Commission européenne à travers les projets d'infrastructures de recherche Eu-ARTECH (FP6 -RII3-CT-2004-506171) et CHARISMA (FP7 GA n. 228330).

\section{Acknowledgements}

The MOLAB activities described in this work were possible thanks to the support of the European Commission, through the Research Infrastructures projects Eu-ARTECH (FP6-RII3-CT-2004-506171) and CHARISMA (FP7-GA n. 228330).

(Traduction du texte anglais en français : Elsa Bourguignon.)

\section{Bibliographie}

1. Miliani C., Rosi F., Brunetti B. G., Sgamellotti A., 2010, "In situ noninvasive study of artworks: The MOLAB multi-technique approach", Acc. Chem. Res., 43, p. 728-738 et références citées.

2. Brunetti B., Miliani C., Rosi F., Doherty B., Monico L., Romani A., Sgamellotti A., 2016, "Non-invasive investigations of paintings by portable instrumentation: The MOLAB experience", Top. Curr. Chem. 374:10 et références citées.

3. Sgamellotti A., Brunetti B., Miliani C. (eds.), 2014, Science and Art. The Painted Surface, The Royal Society of Chemistry, Cambridge, UK.

4. Topolova-Casadiego B., Daffara C., Patti M., Bellucci R., Frosini C., Fontana R., Miliani C., 2015, "Analysis of Munch's paintings by scanning multispectral infrared reflectography: Anxiety (1894), Puberty (1894) and Vampire (1895)" in Public paintings by Edvard Munch and his contemporaries. Change and conservation challenges, Archetype Publications Ltd., en association avec Conservation Studies, University of Oslo.

5. Monico L., Janssens K., Hendriks E., Vanmeert F., Vander Snickt G., Cotte M., Falkenberg G., Brunetti B. G., Miliani C., 2015, "Evidence for degradation of chrome yellows in Van Gogh's Sunflowers: a study using non-invasive methods and synchrotron-radiation-based X-ray techniques", Angew .Chem. Int. Ed., 54, p. 13923-13927.

6. Monico L., Rosi F., Miliani C., Daveri A., Brunetti B. G., 2013, "Non-invasive identification of metal-oxalate complexes on polychrome artwork surfaces by reflection mid-infrared spectroscopy", Spectrochim. Acta A, 116, p. $270-280$.

7. Ormsby B., Kampasakali E., Miliani C., Learner T., 2009, "An FTIR based exploration of the effects of wet cleaning treatments on artists' acrylic emulsion paint films", e-Preservation Science, 6, p. 186-195.

8. Jackson J. B., Melis M., Walker G., Giovannacci D., Miccoli M., MartosLevif D., Bowen J., Detalle V., 2015, "Terahertz and multispectral imaging of a Tanda painting", Proc. SPIE 9527, Optics for Arts, Architecture, and Archaeology V, 95270K.

9. Tornari V., Bernikola E., Tsiranidou E., Hatzigiannakis K., Andrianakis M., Detalle V., Bodnar J., 2013, "Micromapping of defect structural micromorphology in the documentation of fresco wall paintings", Int. J. Herit. Digital Era, 2, p. 1-22.

10. Targowski P., Iwanicka M., Rouba B. J., Frosinini C., 2015, "OCT for examination of artwork" in W. Drexler and J.G. Fujimoto (eds.), OCT: Technology and Applications - $2^{\mathrm{e}}$ édition, Springer, p. 2473-2495. 